\title{
VALIDATION OF OPTIMAL ELECTRIC VEHICLE CHARGING STATION ALLOTMENT ON IEEE 15-BUS SYSTEM
}

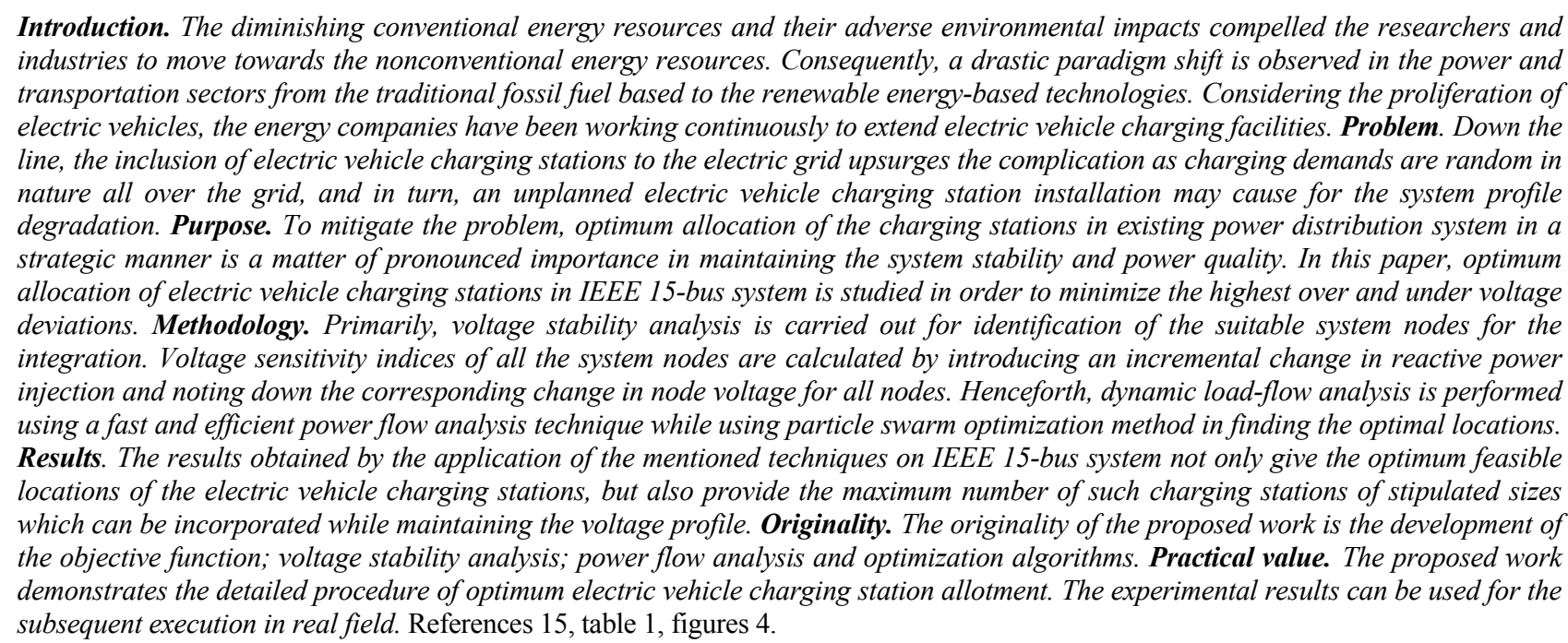
Key words: electric vehicle charging station, optimal allotm analysis, particle swarm optimization.

Вступ. Зменшення традииійних енергетичних ресурсів та їх несприятливий вплив на навколишнє середовище змусили дослідників $і$ галузі промисловості перейти до нетрадииійних енергетичних ресурсів. Отже, в енергетичному та транспортному секторах спостерігається кардинальна зміна парадигми від традиційного викопного палива до технологій, що базуються на відновлюваних джерелах енергії. Беручи до уваги розповсюдження електромобілів, енергетичні компаніі постійно прачюють над розширенням потужностей для зарядки електромобілів. Проблема. Включення зарядних станцій для електромобілів до електричної мережі викликає ускладнення, оскільки вимоги до зарядки мають випадковий характер по всій електромережі, i, в свою чергу, незапланована установка зарядної станції для електромобілів може призвести до погіршення профілю системи. Мета. Щоб полегшити проблему, оптимальне розміщення зарядних станиій в існуючій системі розподілу електроенергії стратегічним чином є питанням надзвичайно важливого значення для підтримки стабільності системи та якості електроенергї. У цій роботі вивчається оптимальне розміщення зарядних станцій для електричних транспортних засобів в 15-иинній системі IEEЕ з метою мінімізачії найвищих відхилень напруги вгору та донизу. Методологія. В периу чергу, проводиться аналіз стабільності напруги для ідентифікаиії відповідних вузлів системи для інтеграції. Показники чутливості до напруги всіх вузлів системи обчислюються шляхом введення поступової зміни подачі реактивної потужності та відмітки відповідної зміни вузлової напруги для всіх вузлів. Надалі динамічний аналіз потоку навантаження виконується за допомогою швидкого та ефективного методу аналізу потоку потужності, використовуючи метод оптимізаиії рою частинок для пошуку оптимальних місиь розташування. Результати. Результати, отримані при застосуванні зазначених методів на 15-иинній системі IEEE, не тільки дають оптимально можливе розташування зарядних станцій електромобілів, але також забезпечують максимальну кількість таких зарядних станцій встановлених розмірів, які можна включити, зберігаючи профіль напруги. Оригінальність. Оригінальність запропонованої роботи полягає у розвитку иілььової функиії; у аналізі стабільності напруги; у алгоритмах аналізу та оптимізації потоку потужності. Практичне значення. Запропонована робота демонструє детальну процедуру оптимального розподілу станиій зарядки електромобілів. Результати експериментів можуть бути використані для подальшої реалізації в реальних умовах. Бібл. 15, табл. 1, рис. 4.

Ключові слова: зарядна станція для електромобілів, оптимальний розподіл, 15-шинна система IЕEЕ, аналіз стабільності напруги, аналіз потоку навантаження, оптимізація рою частинок.

1. Introduction. Presently, the transportation sector is being transformed rapidly to adopt electric vehicles (EVs) as it is an important revolution to circumvent the depletion of conventional energy resources and their detrimental environmental impacts like global warming, public health hazards, etc. [1]. With the proliferation of $\mathrm{EVs}$, there is an equivalent obligation to meet the EV charging needs. In this perspective, a massive infrastructure planning is required towards the installation of electric vehicle charging stations (EVCSs) [2]. Expansion of generation and energy storage planning is the concern to accommodate many EVCSs. The generation extension may be combined with energy storage systems. However, the generation expansion is constrained by several factors like renewable energy integration, rating of existing transmission/distribution lines, investment cost, risk assessment, long-term planning, etc. [3].

Optimal allocation of EVCSs can comfort to accommodate a substantial number of EVCSs in existing power system while sinking power losses and functioning cost in tandem with voltage stability. In recent years, several studies have been carried out in the domain of optimal sizing and allocation of the EVCSs in power distribution networks. In [4], greedy algorithm along with

(C) D. Sengupta, A. Datta 
three other optimization techniques was presented for maximizing the accessibility of EVCS to the EV owners. In [5], a stochastic collaborative planning for EVCS integrated distribution network was performed by utilizing a realistic traffic assignment model in conjunction with conical congestion function. Optimal placement of fast charging EVCSs for charging cost minimization using game theory was proposed in [6]. A multi-objective bi-layer Pareto optimization technique for maximizing EV parking garage profit and minimizing line loss as well as voltage deviation was pronounced in [7]. A multi-agent system (MAS) simulation framework along with evidential reasoning (ER) approach was used for minimizing the charging cost, charging waiting time and charging travel time [8].Optimal allocation of EVCSs for sharing charging level improvement and total charging distance minimization was presented [9]. In [10], a collaborative multi-aggregator EV charging scheduling for PV powered EVCSs for aggregator total profit maximization was accomplished. An optimum distributed energy trading strategy was proposed using game theory on an EVCS incorporated integrated energy system (IES) [11]. A geographic information system (GIS) based technique for PV based EVCS location analysis and evaluation was presented in [12].

Literature review reveals that less amount of work is performed in the domain of EVCS allocation in view of voltage profile retention. Another general shortfall of all these researches is the absence of voltage stability analysis which is vital to check the suitability of the nodes for power injection/absorption while retaining the system stability.

In the present work, an effective strategy for optimal allocation of EVCSs to maintain the voltage profile of a distribution network is presented. Among the different optimization techniques, the particle swarm optimization (PSO) is an easy and distinct convergence technique [13] Thus, PSO technique is adopted in compliance with an efficient dynamic power flow analysis method. IEEE 15-bus system is taken for optimal allocation of EVCSs with respect to minimization of node voltage deviation. The optimum results obtained from the case study are substantiated with the voltage stability analysis results. A comparison of the system voltage profile with EVCS and without EVCS is presented to show the effectiveness of the optimal allocation of EVCSs.

The rest portion of this paper is structured as follows: problem formulation is included in Section 2. Voltage stability analysis is discussed in Section 3. Power flow analysis and PSO technique are described in Sections 4 and 5, respectively, whereas Section 6 presents the proposed power flow analysis collaborated PSO technique in detail. Results and discussion are placed in Section 7, and finally Section 8 concludes the paper.

The aim of the paper is to optimally allocate the maximum number of electric vehicle charging stations of specific sizes while retaining the voltage profile. In turn the system stability, power balance and power quality will be maintained.

2. Problem formulation. Objective function. The integration of several EVCSs into a distribution network can introduce severe voltage deviations in different feeders depending on the power flow. Therefore, optimal sizing and allocation of such EVCSs are very essential in maintaining the voltage deviation within the standard limit. In view of this, an objective function is formulated to minimize the highest voltage rise and drop with respect to the reference voltage.

To objective function is defined as

$$
\text { Minimize } E_{\text {devihighest }}=
$$

$$
\begin{aligned}
& =\text { Minimize }\left|\left(\left\{V_{\text {ref }}-V[F N(i, 1)]\right\},\left\{V_{\text {ref }}-V[F N(i, j+1)]\right\}\right)\right|= \\
& =\text { Minimize }\left(\left\{\left|V_{\text {ref }}\right|-|V[F N(i, 1)]|\right\},\left\{\left|V_{\text {ref }}\right|-\right.\right. \\
& -\left\{|V[F N(i, j)]|-\frac{\sqrt{\left(P_{S}[F B(i, j)]\right)^{2}+\left(Q_{S}[F B(i, j)]\right)^{2}}}{|V[F N(i, j)]|} \times\right. \\
& \times|Z[F B(i, j)]|\}\}) .
\end{aligned}
$$$$
\text { The voltage of the }(j+1)^{\text {th }} \text { node of the } i^{\text {th }} \text { path is }
$$$$
|V[F N(i, j+1)]|=|V[F N(i, j)]|-
$$$$
-\frac{\sqrt{\left(P_{S}[F B(i, j)]\right)^{2}+\left(Q_{S}[F B(i, j)]\right)^{2}}}{|V[F N(i, j)]|} \cdot|Z[F B(i, j)]|,
$$

where $i=1, \ldots, T N$ and $j=1, \ldots, N(i)-1 ; i$ represents the main feeder, lateral or sublateral number of the distribution network; $i^{\text {th }}$ path signifies the paths associated with main feeder, laterals, and sub-laterals; $T N$ is the total number of paths of the network; $j$ is the index for representing the nodes and branches of the $i^{\text {th }}$ path; $N(i)$ is the maximum number of nodes present in the $i^{\text {th }}$ path. As number of branches present in a path is exactly 1 less than the number of nodes, the total number of branches of the $i^{\text {th }}$ path is $N(i)-1$. Henceforth, $[F B(i, j)]$ presents the branches of the $i^{\text {th }}$ path and for $j=N(i)-1,[F B(i, j)]$ denotes the last branch of the associated $i^{\text {th }}$ path. $[F N(i, j)]$ indicates the nodes of the allied $i^{\text {th }}$ path. For $j=N(i)-1$, $[F N(i, j)]$ presents the node just before the last node. $[F N(i, j+1)]$ presents the last node of the $i^{\text {th }}$ path. $E_{\text {devihighest }}$ is the highest voltage (over and under voltage) errors among the node voltages of the distribution system; $V_{\text {ref }}$ is the reference bus voltage, which is taken as $(1+j \cdot 0) \mathrm{pu}$. The voltage of main feeder first node $V[F N(1,1)]=(1+$ $+j \cdot 0)$ pu. $V[F N(i, 1)]$ denotes the first node voltage of the $i^{\text {th }}$ path. $V[F N(i, j)]$ is the $j^{\text {th }}$ node voltage of the $i^{\text {th }}$ path. $Z[F B(i, j)]$ represents the $j^{\text {th }}$ branch impedance of the $i^{\text {th }}$ path. $P_{S}[F B(i, j)]$ and $Q_{S}[F B(i, j)]$ are the active and reactive power flows of the $[F B(i, j)]$ branch.

\section{Decision variables. EVCS locations.}

An array named EVCSLOCS is assigned to store the decision variables of the proposed optimization problem, i.e., the randomly generated EVCS locations

$$
\begin{aligned}
& E V C S L O C S=\left[E_{\text {VCSLOCS }}, \ldots, \text { EVCSLOCS }_{i}, \ldots,\right. \\
& \left., \ldots, \mathrm{EVCSLOCS}_{n}\right] \text {, }
\end{aligned}
$$

where $E V C S L O C S_{i}$ denotes the $i^{\text {th }}$ EVCS location among total $n$ number of EVCS locations.

The operating range of EVCSLOCS $i$ is restricted to $[F N(i, j)]$; for $i=1, j=2, \ldots, N(i)$ and for $i=2, \ldots, T N$, $j=1, \ldots, N(i)$. The total number of EVCSs $(n)$ varies based on the requirements of different case studies.

\section{Maximum powers of the EVCSs.}

Two arrays named $P_{E V s t n}$ and $Q_{E V s t n}$ are assigned to hold the active and reactive power capacities of the EVCSs 


$$
\begin{aligned}
& P_{E V s t n}=\left[P_{E V s t n 1}, \ldots, P_{E V s t n i}, \ldots, P_{E V s t n n}\right] ; \\
& Q_{E V s t n}=\left[Q_{E V s t n 1}, \ldots, Q_{E V s t n i}, \ldots, Q_{E V s t n n}\right],
\end{aligned}
$$

where $n$ is the numbers of EVCSs are to be allocated; $P_{E V s t n i}$ and $Q_{E V s t n i}$ are an active and reactive power capacities of $i^{\text {th }}$ EVCS $\left(\mathrm{EVCS}_{i}\right)$ respectively.

\section{Bus voltage constraints.}

$$
V_{\min } \leq V[F N(i, j)] \leq V_{\max }
$$

where $V[F N(i, j)]$ represents the node voltages of the distribution network.

The $V_{\min }$ and $V_{\max }$ are taken as $0.9 \mathrm{pu}$ and $1.1 \mathrm{pu}$ respectively for primary distribution.

3. Voltage stability analysis. Voltage stability analysis is a mandate to identify the suitable nodes appropriate for load point integration [14] in view of retaining the overall system stability. For checking the stability of the network due to integration of EVCS at different nodes accept the swing bus, the voltage sensitivity analysis of all these nodes is essential. For a decoupled network, the voltage sensitivity is dominantly reliant on its reactive power sensitivity $\left(\delta Q_{n} / \delta V_{n}\right)$. The voltage sensitivity index (VSI) for $n^{\text {th }}$ node is defined as

$$
\left.V S I\right|_{n}=\frac{\delta V_{n}}{\delta Q_{n}} .
$$

where $\delta Q_{n}$ and $\delta V_{n}$ represent the incremental changes in $n^{\text {th }}$ node reactive power $Q_{n}$ and voltage $V_{n}$ respectively. The term $\left(\delta Q_{n} / \delta V_{n}\right)$ represents the ratio of the two incremental changes. $\delta V_{n} / \delta Q_{n}$ is the reciprocal of the aforesaid ratio. It denotes the incremental change in node voltage $\delta V_{n}$ subjected to a corresponding incremental change in reactive power $Q_{n}$ and is called the VSI of the $n^{\text {th }}$ node.

Positive value of VSI indicates a suitable node for load point inclusion, whereas, negative VSI implies an unstable node. The less value of positive VSI infers a more stable node and vice versa.

4. Power flow analysis. An efficient power flow analysis method [15] is utilized along with the PSO optimization technique for dynamic power flow and node voltage calculation. The governing equations of this method are

$$
\begin{gathered}
\left|I[F B(i, j)]_{\text {new }}\right|=\frac{\left|V[F N(i, j)]_{\text {old }}\right|-\left|V[F N(i, j+1)]_{\text {old }}\right|}{|Z[F B(i, j)]|} ; \\
L P[F B(i, j)]_{\text {new }}=\left|I[F B(i, j)]_{\text {new }}\right|^{2} \cdot R[F B(i, j)] ; \\
L Q[F B(i, j)]_{\text {new }}=\left|I[F B(i, j)]_{\text {new }}\right|^{2} \cdot X[F B(i, j)] ;(10) \\
\left|V[F N(i, j+1)]_{\text {new }}\right|=\left|V[F N(i, j)]_{\text {new }}\right|- \\
-\frac{\sqrt{\left(P_{S}[F B(i, j)]\right)_{\text {new }}{ }^{2}+\left(Q_{S}[F B(i, j)]\right)_{\text {new }}}}{\left|V[F N(i, j)]_{\text {new }}\right|} \times
\end{gathered}
$$$$
\times|Z[F B(i, j)]|,
$$

where, $i=1, \ldots, T N$ and $j=1, \ldots, N(i)-1$. The notations used in this section are like the notations mentioned in «objective function» section. $V[F N(i, j)], I[F B(i, j)]$, $L P[F B(i, j)]$ and $L Q[F B(i, j)]$ are the relevant node voltage, line current, line active and reactive power losses respectively. The active and reactive power flows from the branch $[F B(i, j)]$ are $P_{S}[F B(i, j)]$ and $Q_{S}[F B(i, j)]$ respectively, which are dependent upon the values of
$L P[F B(i, j)], L Q[F B(i, j)], P_{L}[F N(i, j)], Q_{L}[F N(i, j)]$ and the system configuration. $P_{L}[F N(i, j)]$ and $Q_{L}[F N(i, j)]$ are the load active and reactive powers connected to the $[F N(i, j)]$ node. The subscript «new» represents the running iteration of power flow, whereas subscript «old» denotes the previous iteration.

5. PSO algorithm. PSO [13] is a population-driven algorithm which shows a good resemblance with the flock of birds searching for food in a search space. The entire population is called the swarm and individual members of the swarm are called particles. In contrast to the conventional optimization techniques, PSO gives faster convergence, identification of global optima in presence of local optima along with the features of simplicity in programming and adaptability for the constrained problems.

The governing equations for PSO algorithm are

$$
\begin{aligned}
& V_{i}(t)=\omega(t) \cdot V_{i}(t-1)+c_{1} \cdot r_{1} \cdot\left(P_{i}(t-1)-X_{i}(t-1)\right)+ \\
& +c_{2} \cdot r_{2} \cdot\left(G(t-1)-X_{i}(t-1)\right)
\end{aligned}
$$

and

$$
X_{i}(t)=X_{i}(t-1)+V_{i}(t),
$$

where $X_{i}$ and $V_{i}$ symbolize the position and velocity of the $i^{\text {th }}$ particle, and are denoted by $X_{i}=\left[x_{i 1}, \ldots, x_{i n}\right]$ and $V_{i}=\left[v_{i 1}, \ldots, v_{i n}\right]$. These are the arrays, which contain the position and velocity of the $i^{\text {th }}$ particle. $P_{i}$ and $G$ are the arrays containing the local best position of the $i^{\text {th }}$ particle and global best position of all the particles of the swarm ever visited in each iteration. Symbol «t» represents the current iteration number and $(t-1)$ signifies the previous iteration number, $1 \leq t \leq I T_{\max }$, where $I T_{\max }$ is the maximum iteration number.

When $t=1$ the $V_{i}(t-1), X_{i}(t-1), P_{i}(t-1)$ and $G(t-1)$ present $V_{i}(0), X_{i}(0), P_{i}(0)$ and $G(0)$ respectively. These are the $0^{\text {th }}$ iteration (initial) values of velocity, position, best position of $i^{\text {th }}$ particle and global best position of the entire swarm. Before starting the iteration process, initialization of all the particles' position, velocity, particles' best position and global best position of the entire swarm is accomplished. The entire swarm size or population of all the particles is denoted by $n_{p o p}$. Therefore, $1 \leq i \leq n_{p o p}$. At first, $x_{i 1}$ to $x_{i n}$ (the positions of $n$ numbers of decision variables) of all the particles are initialized by generating random values in $n$ dimensional search space. Velocities $\left(V_{i}\right)$ of all the particles are initialized by storing zeros. After initialization of particles' position and velocity arrays, the objective function is calculated. Particle's best position $P_{i}$ is initialized by assigning the same initial random values stored inside the $X_{i}$ array for all particles. Particle's initial objective function value is stored inside the particle's best objective function array for initialization. Global best objective function is initialized by taking ( 0 ) or (inf) for the maximization and minimization problems respectively. Gradually, with the initialization of each particle's best values; continuous updating of global best values (global best position $G$ along with global best objective function value) for the entire swarm is completed to achieve the final initialized global best values. $\omega$ is the inertia coefficient. At first iteration, usually its value is taken as 1 for the entire swarm and gradually at successive iterations, its value decreases to 
almost zero if damping inertia coefficient, $\omega_{\text {damp }}$ is introduced. $\omega(t)=\omega(T-1) \cdot \omega_{\text {damp }} . c_{1}, c_{2}$ are the cognitive and social parameters respectively, and $r_{1}, r_{2}$ denote random numbers.

6. Power flow coordinated PSO technique. To attain minimum values of highest over and under voltage deviations ( $E_{\text {overvol } h}$ and $E_{\text {undervol- } h}$ ) in accommodating multiple numbers of EVCSs in a distribution network, PSO is exploited with power flow method. The maximum power handling capacities of EVCSs are selected considering different relevant factors. After selection of the EVCS capacities, the next step is to generate random

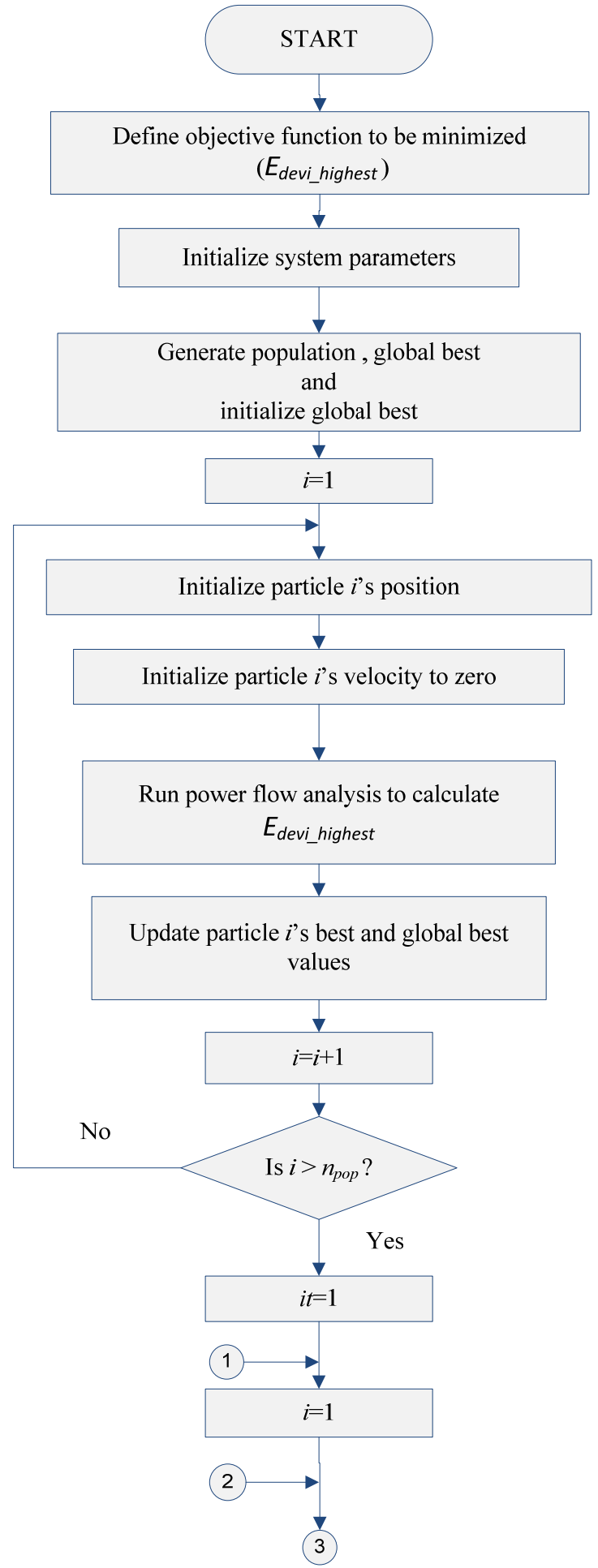

EVCS locations within the lower and upper bounds of distribution feeder to initialize the entire swarm. These random EVCS locations generated inside the PSO algorithm for each particle are sent chronologically inside the power flow analysis function as input arguments. System data along with the EVCS capacities are encumbered inside the power flow algorithm. The distribution network data is updated inside the power flow algorithm based on these random EVCS locations. The power flow algorithm executes concurrently with the PSO method. Figure 1 shows the flow chart of the proposed power flow coordinated PSO technique.

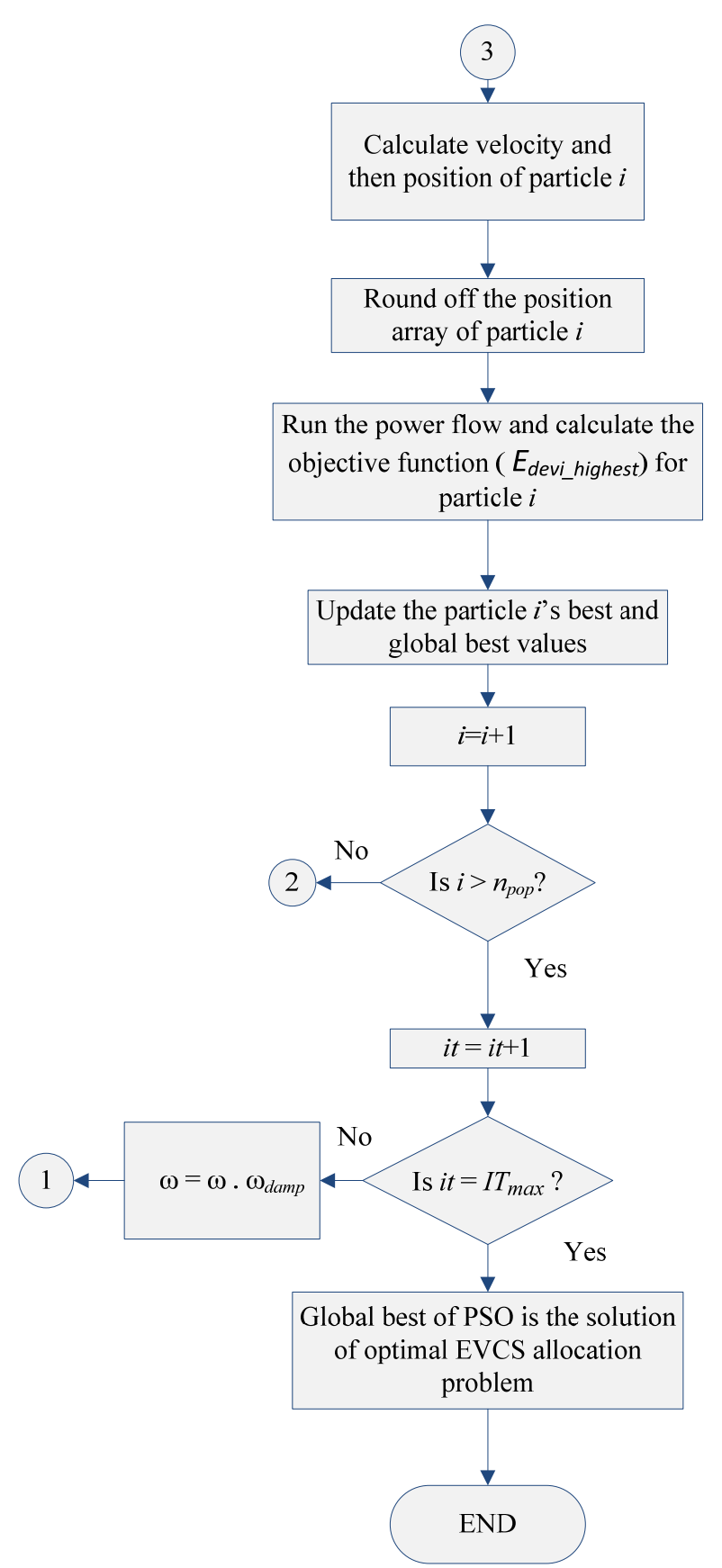

Fig. 1. Flow chart of the power flow coordinated PSO technique 
7. Results and discussion. The IEEE 15-bus radial distribution system, shown in Fig. 2 is taken for the case study. The active and reactive power demands are 1126.5 $\mathrm{kW}$ and $1251.182 \mathrm{kVAR}$ respectively. The base values are chosen as $100 \mathrm{MVA}, 11 \mathrm{kV}$. The normalized voltage sensitivity indices of all nodes are calculated by finding out the $\delta V_{n} / \delta Q_{n}$ value of the $n^{\text {th }}$ node, where $n=[F N(i, j)]$, excluding the main feeder first node. For this purpose, an incremental change in reactive power of the $n^{\text {th }}$ node is introduced and the corresponding incremental change in node voltage is obtained by applying power flow analysis. Figure 3 presents the normalized voltage sensitivity indices of the test network.

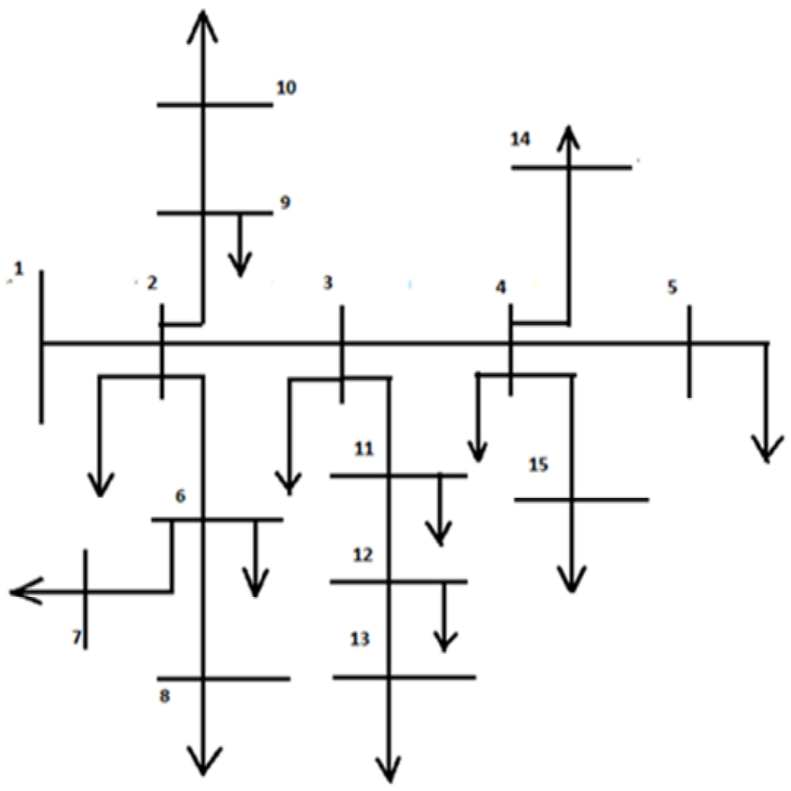

Fig. 2. IEEE 15-bus system

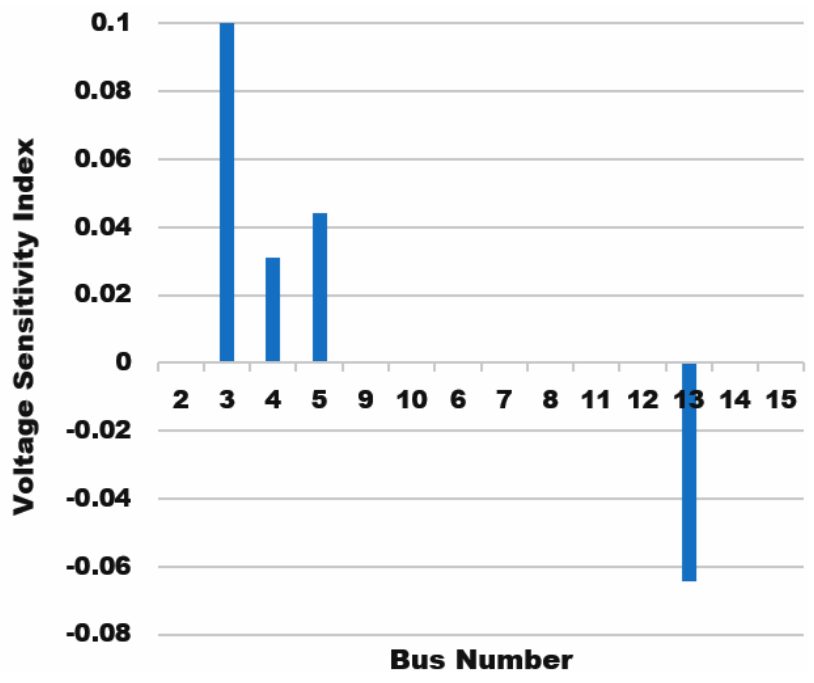

Fig. 3. Normalized voltage sensitivity indices of 15-bus system

It is observed that node number 13 is inappropriate for power injection or extraction into the system as the VSI value of this node is negative. Other nodes are having positive VSIs and guarantee the sustained stability of the system. But amidst them, node numbers 3, 4 and 5 attain high values of VSI. Therefore, these are the comparatively weaker nodes. Amongst these three nodes, node 3 is unsuitable for power injection as the VSI value of this node is very high. The other two nodes, i.e. nodes 4 and 5, can be considered for EVCS integration. After sensitivity analysis, gradually augmented numbers of identical EVCSs are approached to investigate the effect of newly integrated EVCSs upon the system voltage profile. The motive is to find out the maximum number of such EVCSs that the network can accommodate without compromising the voltage profile. The proposed power flow collaborated PSO technique is utilized for this purpose. For the execution of the PSO algorithm, the value of $\omega_{\text {damp }}$ is taken as $0.99 . c_{1}$ and $c_{2}$ are set to 0.5 each. $r_{1}$ and $r_{2}$ are taken from the uniform distribution interval [0 1]. For deciding the capacity of each EVCS, maximum $2 \mathrm{EV}$ charging requirement per EVCS is considered. Considering $8 \mathrm{~kW}$ DC charger, the total power consumed by $2 \mathrm{EVs}$ are $16(2 \times 8) \mathrm{kW}$ DC. Rectifier efficiency is $90 \%$. Henceforth, the rectifier input power is $17.78(16 \times 100 / 90) \mathrm{kVA}$ AC. Taking grid load power factor as 0.7 , the active and reactive powers drawn from the grid by each EVCS are $12.446(17.78 \times 0.7) \mathrm{kW}$ and $12.7(17.78 \times 0.7141) \mathrm{kVAR}$ correspondingly. The per unit values of these powers are $0.00012446 \mathrm{pu}$ and $0.000127 \mathrm{pu}$. Four trials are carried out considering 2, 3, 4 and 5 EVCS allocation. In each trial, the global best values i.e. optimum values of highest over and under voltage deviations ( $E_{\text {overvol-h }}$ and $\left.E_{\text {undervol-h}}\right)$ along with the optimum EVCS locations are captured. The results are illustrated in Table 1.

Table 1

Optimum feasible EVCS locations for gradually augmented

EVCS numbers along with the optimum voltage errors

\begin{tabular}{|c|c|c|c|c|c|c|c|}
\hline $\begin{array}{c}\text { No. of } \\
\text { EVCSs } \\
\downarrow\end{array}$ & \multicolumn{3}{|c|}{$\begin{array}{c}\text { Optimum feasible } \\
\text { EVCS Locations } \rightarrow\end{array}$} & \multicolumn{2}{|c|}{$\begin{array}{c}E_{\text {overvol- } h} \\
\text { (in pu) }\end{array}$} & $\begin{array}{c}E_{\text {undervol- } h} \\
\text { (in pu) }\end{array}$ \\
\hline 2 & 9 & 10 & & & & 0.0472 & 0 \\
\hline 3 & 8 & 9 & 10 & & & 0.0475 & 0 \\
\hline 4 & $\mathbf{7}$ & $\mathbf{8}$ & $\mathbf{9}$ & $\mathbf{1 0}$ & & $\mathbf{0 . 0 4 7 8}$ & $\mathbf{0}$ \\
\hline 5 & 3 & 8 & 9 & 10 & 10 & 0.483 & 0 \\
\hline
\end{tabular}

From the results, it is seen that maximum 4 numbers of EVCSs of stipulated sizes are feasible to be integrated at optimum locations 7, 8, 9 and 10. Increasing the EVCS number to 5 gives two repeated optimum locations at node number 10 which is not suitable for implementation. The optimum nodes 7, 8, 9 and 10 achieved from this case study are verified with the results of sensitivity analysis and found to be satisfactory. The highest over and under voltage errors are substantially lesser $(0.0033 \mathrm{pu}$ and $0 \mathrm{pu})$ compared to the stipulated voltage errors limits $( \pm 0.1 \%)$. That's why these locations are considered as the optimum locations for EVCS integration.

Figure 4 shows a comparison in between the voltage profiles of the system with EVCS and without EVCS. From this analysis, it is observed that voltage profile of the system with EVCS is far better than that of without EVCS. For the system without EVCS, the highest over and under voltage errors are $0 \mathrm{pu}$ and $0.0554 \mathrm{pu}$, respectively. 


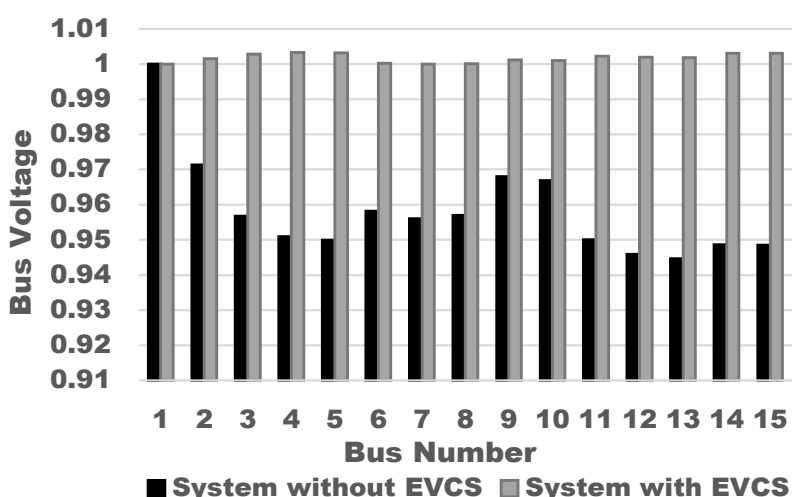

Fig. 4 Comparison of node voltage profile with and without EVCS for 15-bus system

\section{Conclusions.}

Optimal allocation of electric vehicle charging stations in an existing power distribution system is of great importance for maintaining voltage profile. An effective strategy, i.e. power flow analysis coordinated with particle swarm optimization, is applied for the deployment of electric vehicle charging stations in a distribution network with the intention of optimal power flow and voltage profile improvement. Voltage stability analysis is carried out by calculating the voltage sensitivity indices of the network nodes to identify the suitable nodes for the integration. IEEE 15 -bus system is taken to validate the usefulness of the anticipated procedure. Comparison of system voltage profiles with and without electric vehicle charging stations is presented to reveal the effectiveness of the optimal allocation with the proposed strategy.

Conflict of interest. The authors declare that they have no conflicts of interest.

\section{REFERENCES}

1. Xu X., Yao L., Zeng P., Liu Y., Cai T. Architecture and performance analysis of a smart battery charging and swapping operation service network for electric vehicles in China. Journal of Modern Power Systems and Clean Energy, 2015, vol. 3, no. 2, pp. 259-268. doi: https://doi.org/10.1007/s40565-015-0118-y. 2. Fathabadi H. Novel solar powered electric vehicle charging station with the capability of vehicle-to-grid. Solar Energy, 2017, vol. 142, pp. 136-143. doi: https://doi.org/10.1016/j.solener.2016.11.037.

3. Mehrjerdi H. Dynamic and multi-stage capacity expansion planning in microgrid integrated with electric vehicle charging station. Journal of Energy Storage, 2020, vol. 29, no. 101351, pp. 1-11. doi: https://doi.org/10.1016/j.est.2020.101351.

4. Lam A. Y. S., Leung Y.-W., Chu X. Electric vehicle charging station placement: formulation, complexity, and solutions. IEEE Transactions on Smart Grid, 2014, vol. 5, no. 6 , pp. 2846-2856. doi: https://doi.org/10.1109/tsg.2014.2344684.

5. Wang S., Dong Z. Y., Luo F., Meng K., Zhang Y. Stochastic collaborative planning of electric vehicle charging stations and power distribution system. IEEE Transactions on Industrial Informatics, 2018, vol. 14, no. 1, pp. 321-331. doi: https://doi.org/10.1109/tii.2017.2662711.

6. Xiong Y., Gan J., An B., Miao C., Bazzan A. L. C. Optimal electric vehicle fast charging station placement based on game theoretical framework. IEEE Transactions on Intelligent Transportation Systems, 2018, vol. 19, no. 8, pp. 2493-2504. doi: https://doi.org/10.1109/tits.2017.2754382.

7. Faddel S., Elsayed A. T., Mohammed O. A. Bilayer multiobjective optimal allocation and sizing of electric vehicle parking garage. IEEE Transactions on Industry Applications, 2018, vol. 54, no. 3, pp. 1992-2001. doi: https://doi.org/10.1109/tia.2018.2803151.

8. Jiang C., Jing Z., Ji T., Wu Q. Optimal location of PEVCSs using MAS and ER approach. IET Generation, Transmission \& Distribution, 2018, vol. 12, no. 20, pp. 4377-4387. doi: https://doi.org/10.1049/iet-gtd.2017.1907.

9. Gong D., Tang M., Buchmeister B., Zhang H. Solving location problem for electric vehicle charging stations - a sharing charging model. IEEE Access, 2019, vol. 7, pp. 138391138402. doi: https://doi.org/10.1109/access.2019.2943079.

10. Gupta V., Konda S.R., Kumar R., Panigrahi B.K. Collaborative multi-aggregator electric vehicle charge scheduling with $\mathrm{PV}$-assisted charging stations under variable solar profiles. IET Smart Grid, 2020, vol. 3, no. 3, pp. 287-299. doi: https://doi.org/10.1049/iet-stg.2019.0088.

11. Wang Y., Wang X., Shao C., Gong N. Distributed energy trading for an integrated energy system and electric vehicle charging stations: A Nash bargaining game approach. Renewable Energy, 2020, vol. 155, pp. 513-530. doi: https://doi.org/10.1016/j.renene.2020.03.006.

12. Zhou J., Wu Y., Wu C., He F., Zhang B., Liu F. A geographical information system based multi-criteria decisionmaking approach for location analysis and evaluation of urban photovoltaic charging station: A case study in Beijing. Energy Conversion and Management, 2020, vol. 205, no. 112340, pp. 121. doi: https://doi.org/10.1016/j.enconman.2019.112340.

13. Qu B., Li C., Liang J., Yan L., Yu K., Zhu Y. A selforganized speciation based multi-objective particle swarm optimizer for multimodal multi-objective problems. Applied Soft Computing, 2020, vol. 86, no. 105886, pp. 1-28. doi: https://doi.org/10.1016/j.asoc.2019.105886.

14. Roy P., Das P.K. Reactive power sensitivity index based voltage stability analysis to a real system $(400 \mathrm{kV}$ system of WBSEB). International Journal of Electronics \& Communication Technology, 2013, vol. 4, no. Spl-1, pp. 167169. Available at: iject.org/vol4/spl1/c0055.pdf (accessed 12 October 2020).

15. Ghosh S., Sherpa K.S. An efficient method for load-flow solution of radial distribution networks. International Journal of Electrical and Computer Engineering, 2008, vol. 2, no. 9, pp. 2094-2101. Available at: publications.waset.org/8855/anefficient-method-for-loadflow-solution-of-radial-distributionnetworks (accessed 12 October 2020).

Received 27.03.2021 Accepted 03.05.2021

Published 25.06.2021

Debaparna Sengupta ${ }^{1}$, PhD Student, Assistant Professor, Asim Datta ${ }^{2}$, PhD, Associate Professor,

${ }^{1}$ Department of Electrical Engineering, Techno International New Town,

Rajarhat, Kolkata-700156, Kolkata, India,

e-mail: imdebaparna@gmail.com (Corresponding author)

${ }^{2}$ Department of Electrical Engineering,

Mizoram University,

Aizawl-796004, Mizoram, India,

e-mail: asimdatta2012@gmail.com

How to cite this article:

Sengupta D., Datta A. Validation of optimal electric vehicle charging station allotment on IEEE 15-bus system. Electrical Engineering \& Electromechanics, 2021, no. 3, pp. 68-73. doi: https://doi.org/10.20998/2074-272X.2021.3.11. 